Ann. Biol. anim. Bioch. Biophys., 1978, 18 (2 B), 595-605.

\title{
Functional characteristics of rat Leydig cells
}

\author{
by K. PURVIS, O. P. F. CLAUSEN, V. HANSSON \\ Institute of Pathology, Rikshospitalet, Oslo, Norway.
}

Summary. Rat Leydis cells within the same testis population exhibit variable degrees of histochemical reaction to $3 \beta$ hydroxy steroid dehydrogenase ( $3 \beta$ HSD) staining and variable $\mathrm{LH}$ binding when examined by immunofluorescence labelling. It is concluded that rat Leydig cells may represent discrete functional units within a heterogenous cell population with possible individual sensitivities to $\mathrm{LH}$ and different steroidogenic capacities.

The in vitro responsiveness of Leydig cells to a constant dose of hCG $(3 \mathrm{ng} / 2 \mathrm{ml})$ changes between 30 and 80 days of age. The magnitude and direction of the change depends on the response parameter being used. When testosterone was used as the index of response, Leydig cells exhibited an increasing steroidogenic capacity and responsiveness with increasing age. When assessed in terms of $17 \beta$-hydroxy androgen secretion (testosterone $+5 \alpha$ reduced metabolites), the trend was reversed. This contradiction emphasises the importance of using the correct parameter for evaluating the steroidogenic capacity and $h C G / L H$ responsiveness of rat Leydig cells.

A single injection of hCG (75 IU) into normal rats induced a 80-90 p. 100 reduction in LH receptors in testicular membrane particles after three days. Associated with this decrease in the receptor population was a reduction in the sensitivity of the in vitro response of the Leydig cells to hCG. The maximum response to the highest levels of hCG was unaffected. Alterations in the number of $\mathrm{LH}$ receptors have to be more than $30 \mathrm{p} .10 \mathrm{C}$ before any obvious effects on the steroidogenic response of the Leydig cells are recorded. These effects of $\mathrm{LH}$ on the $\mathrm{LH}$ receptor and Leydig cell response are discussed as a possible explanation for the observed reduction in LH binding and the diminished sensitivity of Leydig cell response to hCG observed in the syndrome of testicular feminisation, a condition associated with highly elevated endogenous LH levels. Clomiphene treatment of normal male rats induced a 2-3 fold increase in endogenous LH levels which was associated with a 40 p. 100 reduction in the number of $\mathrm{LH}$ receptors on Leydig cell membrane particles. It is suggested that under normal conditions, endogenous $\mathrm{LH}$ level can be stimulated to a point where if influences the levels of its own receptor.

Prolactin treatment of hypophysectomised rats caused a stimulation in the number of $\mathrm{LH}$ receptors on Leydig cell membranes. Cyproterone and dihydrotestosterone propionate (DHTP) had no effect on the LH receptor population but diminished Leydig cell function by an effect on the steroidogenic enzymes.

\section{Introduction.}

It is becoming increasingly evident that Leydig cell function may be under the control of not one but several hormones. In addition to the presence of $\mathrm{LH}$ receptors on Leydig cell membranes (Catt et al., 1974), it has also been demonstrated that Leydig cells contain receptors for androgens (Sar et al., 1975 ; Wilson and Smith, 1975), 
œstrogens (Mulder et al., 1974), glucocorticoids (Evain, Morera and Saez, 1976) and prolactin (Charreau et al., 1977), suggesting that also these hormones may exert some influence on Leydig cell function at least during certain phases of testicular development. Confirmation of such hormonal influences can only come from experiments where the effects of the individual hormones on Leydig cell function can be studied in isolation, either in vivo or in vitro. The present paper reports certain of our studies on the influence of various hormones on rat Leydig cell function, but first describes some of the basic properties of rat Leydig cells which are important considerations for the interpretation of these hormonal effects.

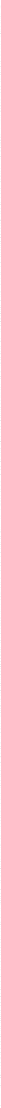

PLATE

Cells from an enriched Leydig cell suspension stained for $3 \beta$-hydroxy steroid dehydrogenase. After collagenase dispersion of the adult rat testes, the pellet of cells was smeared and air dried. The smear was incubated at $37 \mathrm{C}$ for $1 \mathrm{hr}$ in Krebs Ringer buffer containing Nitro blue tetrazolium $(0.14 \mathrm{~g} / \mathrm{l})$, Nicotinamide $(0.16 \mathrm{~g} / \mathrm{l})$, NAD $(0.27 \mathrm{~g} / \mathrm{l})$ and 4-androsten-3 $\beta$-ol-17-one $(0.4 \mathrm{~g} / \mathrm{l})$. Note marked intracellular varation in the amount of formazan in the positive cells. 


\section{Results and discussion.}

Assynchrony of function within the Leydig cell population.

Aside from their morphological characteristics, two properties of rat Leydig cells can be used to distinguish them from other testicular cells in a histological section or in a cell suspension : they possess the enzyme $3 \beta$ hydroxy steroid dehydrogenase ( $3 \beta$ HSD) which can be demonstrated histochemically, and they bind $L H$, a feature which can be visualised using immunofluorescence techniques. Plate I shows cells from an enriched Leydig cell suspension which have been stained for $3 \beta$ HSD using the technique described by Purvis, Clausen and Hansson (1978a). It is apparent that Leydig cells in the same suspension exhibit marked variation in the intensity of staining, an observation which implies that under normal in vivo conditions, the steroidogenic activity of the Leydig cell population is not synchronised. Similarly, when the LH receptors on the Leydig cell surface are rendered visible by immunofluorescent labelling (Purvis ef al., 1978a), major differences in the intensity of fluorescence are consistently found between cells of the same population (Plate II). Such a finding suggests

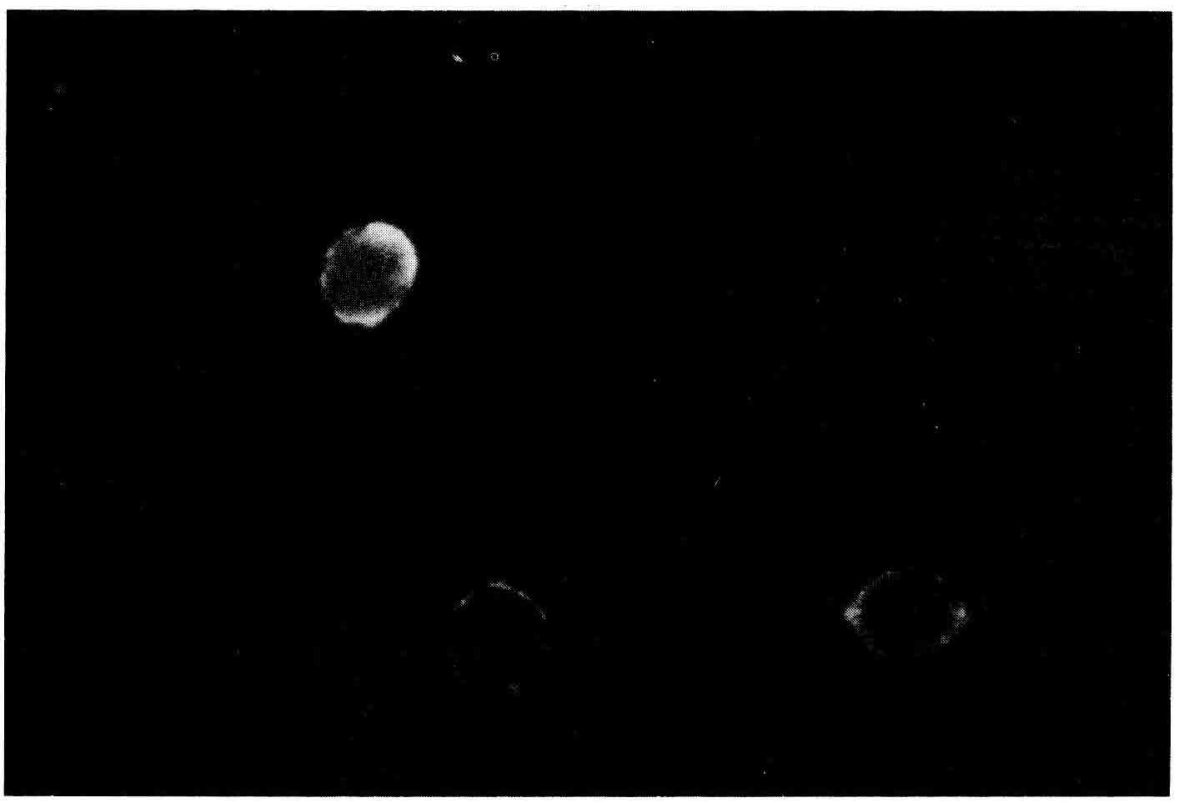

PLATE \|

Immunofluorescence labelling of hCG/LH receptors in three cells from on enriched Leydig cell suspension. Affer collagenase dispersion, cells were incubated sequentially with 75 IU hCG, the IgG fraction of anti-hCG labelled with tetramethylrhodamine isothiocyanate (MRITC) and a MRITC conjugate of goat antiserum raised to rabbit IgG. Cells were examined under a Leitz Orthoplan microscope. For further details of the technique consult Purvis ef al., 1978a. The three cells exhibit marked variation in the intensity of fluorescence indicating differences in LH binding capacities. 
that the LH binding capacity of each Leydig cell is not uniform and, as can be appreciated later, that different cells may therefore exhibit different sensitivities to $\mathrm{LH}$ under normal conditions. This intercellular variation in steroidogenic function and LH binding may be taken as indirect evidence for a local, intracellular control of Leydig cell activity, a possibility which has important implications in the interpretation of hormonal effects on the Leydig cell population as a whole.

Alterations in Leydig cell responsiveness with age ; the importance of the right hormonal parameter.

Certain groups have proposed that the responsiveness of the rat Leydig cell to hCG/LH gradually increases throughout sexual development (Odell ef al., 1974 ; Payne ef al., 1977). However, in these and other studies, the parameter of secretory function has been, without exception, testosterone. This is in spite of the plethora of publications demonstrating that at certain ages (25-45 days) the major product of the rat testis is not testosterone but the $5 \alpha$ reduced derivatives of testosterone, especially $5 \alpha$-androstan-3 $\alpha, 17 \beta$-diol (ADIOL) (Nayfeh, Barefoot and Baggett, 1966 ; Steinberger and Ficher, 1968 ; Strickland, Nayfeh and French, 1970 ; Coffey, French and Nayfeh, 1971 ; Matsumoto and Yamada, 1973). Figure 1 (lower panel) shows that when testosterone was used as the response parameter, a substantial increase in the apparent in vitro responsiveness of decapsulated testes to $3 \mathrm{ng} \mathrm{hCG}$ was observed with increasing age. However, when Leydig cell secretory activity was quantitated using a less specific end point involing the measurement of testosterone, dihydrotes-

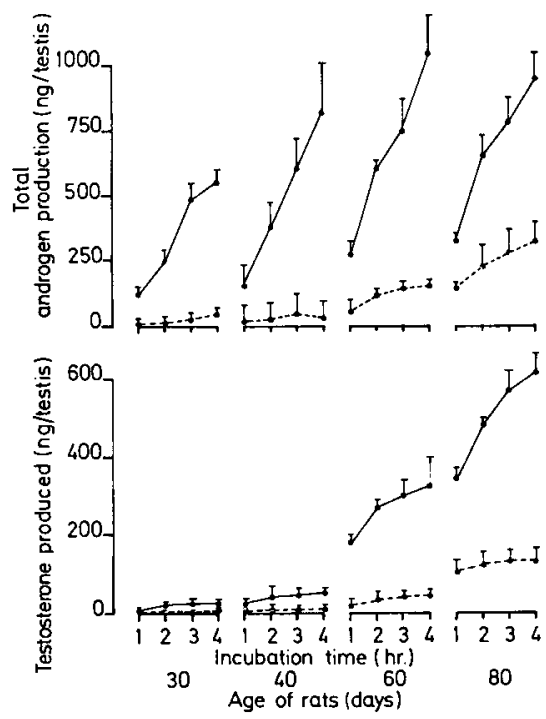

FIG. 1. - In vitro response of decapsulated testes for $30,40,60$ and 80 day rats $(\mathrm{n}=5)$ to $h C G(3 \mathrm{ng} / 2 \mathrm{ml})$. Responses are expressed as testosterone production (lower panel) and total $17 \beta$-hydroxy androgen production (upper panel). Broken line represents basal unstimulated secretion. Vertical bars are standard deviations. 
tosterone, ADIOL and $5 \alpha$-androstan- $3 \beta, 17 \beta$-diol (total $17 \beta$ hydroxy androgen), the apparent differences in responsiveness indicated by testosterone secretion alone were considerably reduced (fig. 1, upper panel). Moreover, since the number of Leydig cells per testis increases 3-10 fold between days 30 and 60 (Clegg, 1966 ; Knorr, Vanha-Pertłula and Lipsett, 1970 ; Pahnke, Leidenberger and Künzig, 1975), there must be a major decrease in the steroidogenic potential and responsiveness to hCG of the individual Leydig cell with increasing age. Confirmation of this possibility was obtained using Leydig cell suspensions (Purvis, Clausen and Hansson, 1978b). A general increase in the maximum quantity of testosterone produced and $\Delta$ (the difference between basal and stimulated levels) was apparent between day 30 and day 60 when the secretion was expressed per million interstitial cells, per million morphological Leydig cells or per million $3 \beta$ HSD positive cells (fig. 2 ). On the other

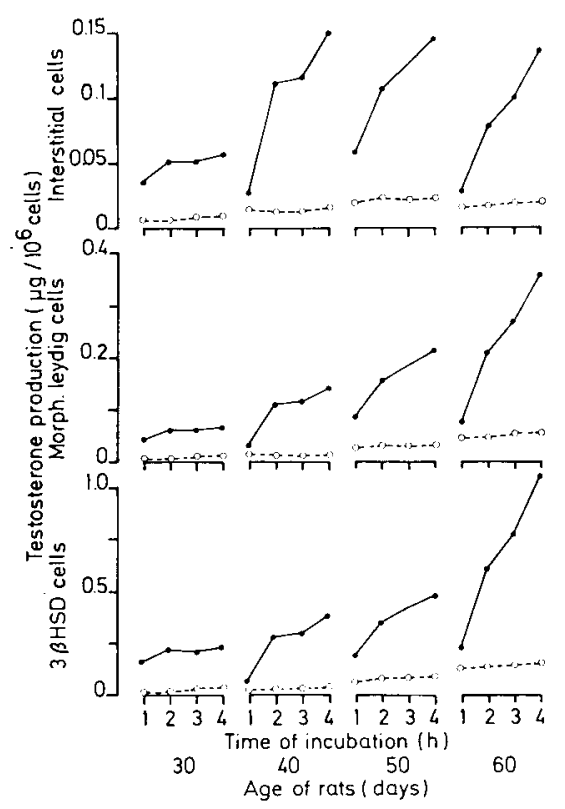

FIG. 2. - In vitro testosterone response of isolated Leydig cell suspensions from 30,40, 50 and 60 day rats to hCG $(3 \mathrm{ng} / 2 \mathrm{ml})$. Pooled suspensions were prepared from six testes. Responses are expressed per million interstitial cells, per million $3 \beta$ positive cells. Broken line represents basal, unstimulated secretion.

hand, this apparent increasing responsiveness of the Leydig cell to hCG in terms of testosterone secretion coincided with a gradual decreased secretion of $17 \beta$ hydroxy androgen (fig. 3). Indeed, both the steroidogenic capacity and HCG responsiveness ( $\Delta$ and the percentage change) underwent a substantial decrease between day 30 and day 60 , and this was true when $17 \beta$ hydroxy androgen secretion was expressed per million interstitial cells, per million morphological Leydig cells or per million $3 \beta$ HSD positive cells. Thus the extensive metabolism of testosterone in immature rat testes 
renders it unsuitable as a response parameter for monitoring $\mathrm{hCG} / \mathrm{LH}$ effects on the Leydig cell in animals less than approximately 50 days of age.

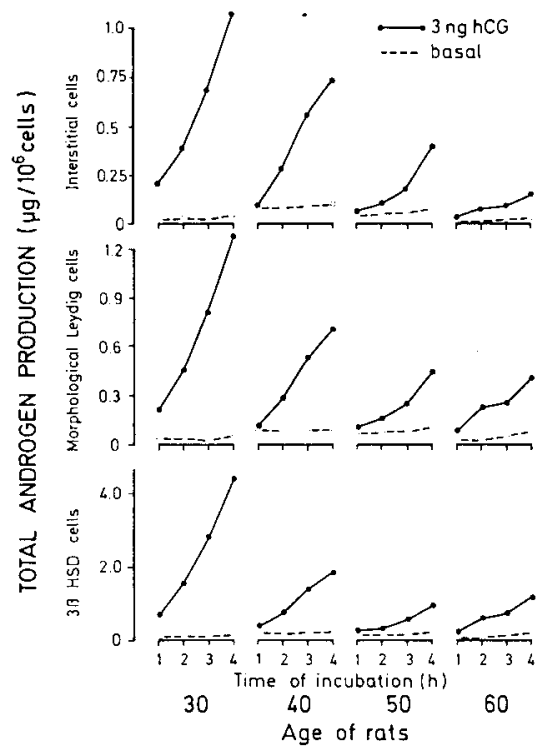

FIG. 3. - In vitro response of isolated Leydig cell suspensions from 30, 40, 50 and 60 day rats to hCG calculated as total $17 \beta$ hydroxy androgen production per million cells. Consult legend to figure 2 for details.

In studies on the effects of drugs or hormones on Leydig cell responsiveness to LH it is important to evaluate the effects not by investigating one component of Leydig cell secretion but by a more general appreciation of changes in the total steroidogenic response. This is especially true if the drug or hormone is known to influence specific testicular enzymes. Under these conditions, although the pattern of steroid metabolites secreted by the testis may be altered, the total quantity of steroids produced may be unchanged and responsiveness relatively unaffected. From the present study it is apparent that rat Leydig cell responsiveness to hCG/LH is decreasing rather than increasing with age, a contradiction which underlines the importance of using the correct response parameter for any studies on Leydig cell responsiveness.

Regulation of Leydig cell function by $L H$ and the relationship befween the $L H$ receptor and responsiveness.

A single injection of 75 IU hCG into adult male rats caused a dramatic reduction in the concentration of membrane receptors for LH in the testis (Purvis ef al., 1977b). The mean receptor level reached a nadir which was 5-10 p. 100 of that in the control testes, three days after the injection, after which it gradually returned to normal. Similar findings have also been reported by other groups (Sharpe, 1976 ; Hsueh, Dufau and Catt, 1976). Such observations raise two important questions. What are the effects of such a reduction in LH receptor number on the response of the Leydig 
cells to LH? Does this autoregulatory process have any physiological significance? In an attempt to answer the first question, Leydig cell suspensions were prepared from immature rat testes, the $\mathrm{LH}$ receptor population of which had been reduced to varying degrees (this was accomplished by preparing the suspension three and five days after the injection of $75 \mathrm{IU} \mathrm{hCG}$ ). The responsiveness of these suspensions to varying doses of hCG was then tested in vitro and compared to that of Leydig cells with a normal receptor complement. Under conditions when the $\mathrm{LH}$ receptor was reduced to approximately 66 p. 100 of its normal level (as revealed by the specific binding of ${ }^{125} \mathrm{~F}-\mathrm{hLH}$ to the intact isolated cells), no major changes were detected in the sensitivity of the Leydig cell response to hCG or in the quantity of androgen secreted when the response was at a maximum (between $0.5-5.0 \mathrm{ng}$ hCG/200 $\mu \mathrm{l}$ ) (fig. 4 , upper panel). However, when receptor binding of LH was reduced to 23 p. 100 of the control value, 5-10 times higher doses of hCG had to be used in order to achieve the same androgen response (fig. 4, lower panel). Although the sensitivity of the response in the latter experiment was greatly reduced, comparable quantities of androgen were produced by both preparations at the highest dose of hCG. The fact that a major reduction in receptor number displaces the dose-steroid response curve to the right, without reducing the maximum steroidogenic response, corroborates

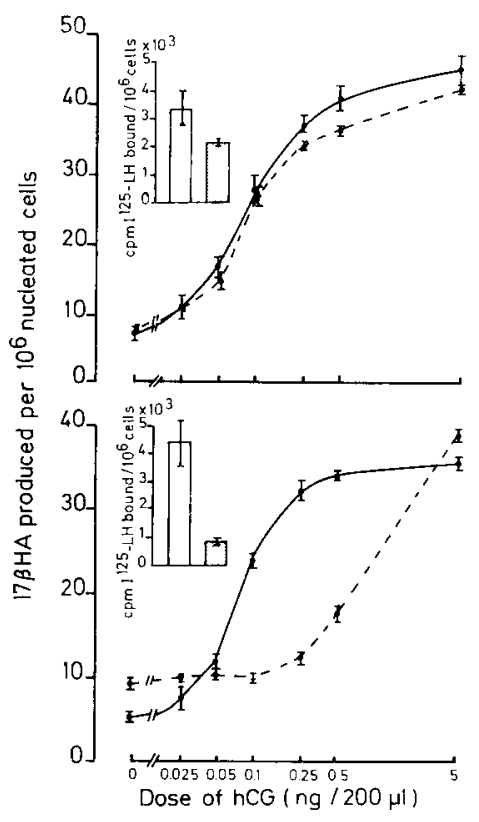

FIG. 4. - In vitro androgen production by hdispersed inferstitial cells from 30 day rat festes, $3 \mathrm{hrs}$ after exposure to varying doses of hCG. Cells were prepared three days (lower panel) and five days (upper panel) after the in vivo injection of saline or $75 \mathrm{IU} \mathrm{hCH}$. The continuous line represents the response of the saline controls, and broken line indicates response of hCG treated prepara. tions. Vertical bars represent one standard deviation of three parallel incubations. Inset indicates specific vinding of ${ }^{125} \mathrm{I}-\mathrm{hLH}\left(\mathrm{cpm} / 10^{6}\right.$ nucleated cells) to intact cells. Open columns represent saline controls, hatched columns indicate hCG-treated. Vertical bars represent one standard deviation of five replicate measurements. 
earlier suggestions (Rodbard, 1973 ; Raff, 1976) that one of the functions of the apparent excess of $\mathrm{LH}$ receptors on the Leydig cell membrane may be to provide a means by which it can modify its responsiveness to LH. On the other hand, it appears that for a hormone or drug to alter Leydig cell responsiveness through an effect on the receptor population, the effect has to be substantial, since relatively small changes in the number of $\mathrm{LH}$ receptors $(<30$ p. 100) appear to be without effect. Immunofluorescence labelling of the $h \mathrm{CG} / \mathrm{LH}$ receptors indicates that the reduction in $125 \mathrm{I}-\mathrm{hLH}$ binding observed after in vivo hCG treatment is the result of a general loss of hCG/LH receptors from the whole population and not a selective loss from a subpopulation of cells (Purvis ef al., 1978a).

The question whether this autoregulation process is of physiological significance is still not answered. The testicular feminised male ( $\mathrm{ffm}$ ) rat possesses a geneticallydetermined relative insensitivity to androgens due to a lack of androgen receptors in the target tissues (Stanley ef al., 1973). One of the manifestations of this androgen insensitivity is that circulating LH levels are elevated eight times the normal (Purvis ef al., 1977a). Also associated with this condition is a markedly reduced number of $\mathrm{LH}$ receptors on the Leydig cell membranes (Purvis ef al., 1976b; Purvis, Clausen and Hansson, 1978c). The possibility cannot therefore be ignored that such an abnormally low number of LH receptors may be a consequence of this elevated LH. Of possibly greater significance is that the $\mathrm{tfm}$ Leydig cells exhibit reduced sensitivity of response to hCG when compared to those from normal animals, but still retain the capacity to respond to a normal degree when exposed to much higher levels of hCG (Purvis, Clausen and Hansson, 1978c). The latter situation is reminiscent of the earlier study when an artificial reduction in the number of $h \mathrm{CG} / \mathrm{LH}$ receptors in the normal rat had similar effects on responsiveness.

Clomiphene treatment $(5 \mathrm{mg} /$ day for 5 days) of 25 -day normal male rats results in elevated plasma LH levels which are 2-3 times that of normal. The LH receptor population in the testis is, under these circumstances, reduced by approximately 40 p. 100. Since similar treatment of hypophysectomised rats revealed no differences in LH binding, this effect of clomiphene cannot be explained by a direct action on the testis. Indeed, it implies that in the normal rat, circulating, endogenous LH levels can be stimulated to a point where this autoregulatory process may start to operate. In this particular experiment the effects of this drug on Leydig cell responsiveness were not tested.

\section{Effects of various treatments on Leydig cell function.}

The finding that Leydig cell function can be modified by simply altering the size of the LH receptor population on its surface, invites the question whether hormones other than LH can exert an influence through the same site.

Treatment of 25-day hypophysectomised male rats with $20 \mu \mathrm{g}$ ovine prolactin (twice daily) for 5 days caused a highly significant stimulation of LH receptors on Leydig cell membranes. No effect was observed on ${ }^{125} \mathrm{I}$-hFSH binding. Conversely, treatment of hypophysectomised rats of the same age with dihydrotestosterone propionate (DHTP, $5 \mathrm{mg} /$ day for 5 days) had no effect on the LH receptor population. However, the magnitude of the in vitro hCG response of the decapsulated testes 
from DHTiP-treated rats was reduced when compared to the controls. Since only one dose of hCG was used in this study, it is impossible to determine whether this reduced response reflects a diminished ability to respond maximally or a lowering in the sensitivity of the response. This difficulty in interpretation underlines the necessity, in any study on hormonal effects on Leydig cells, of examining the responses to multiple doses of $\mathrm{hCG} / \mathrm{LH}$ in order to distinguish between these two possibilities. On the other hand, the negative influence of androgen is unequivocal and raises the intriguing possibility that the major secretory product of the Leydig cell may exert some local feedback control on the steroidogenic response. A third type of hormone interaction on Leydig function is exemplified by the antiandrogen cyproterone. Treatment of 21-day male rats for 9 days with $0.5 \mathrm{mg} /$ day of cyproterone caused a significant reduction in intratesticular and plasma testosterone levels, without affecting the levels of circulating gonadotrophins (Purvis ef al.. 1976a). Such a result implies a direct effect of cyproterone on Leydig cell function. However, treatment of hypophysectomised 25-day rats for 5 days $(5 \mathrm{mg} /$ day) with the same compound, caused no major alterations either in the in vitro testis response to hCG or in the ${ }^{125}$-hLH binding to testis particles. Indeed, it appears that cyproterone exerts its effect directly on the steroidogenic enzymes, not on the receptor-adenyl cyclase apparatus. Exposure of normal adult rat Leydig cells in vitro to increasing doses of cyproterone caused a dose-dependent decrease in the quantity of testosterone secreted in response to a constant dose of hCG. Recent studies from this laboratory indicate that this effect is due to a direct inhibition by this compound on the $3 \beta$ HSDisomerase enzymes of the Leydig cell.

\section{Conclusion.}

Hormone interaction with the Leydig cell is exceedingly complex, not only because of the number of hormones which are potentially involved, but also because of the multiplicity of sites of action where these influences can be exerted. Interpretation of hormone effects on the Leydig cell may be made more easily by considering the following :

1. The Leydig cell population is not functionally synchronised.

2. Developmental changes or hormone treatment may cause qualitative changes in Leydig cell secretion (by altering metabolism) without affecting the total quantity of steroid produced. When assessing the integrity of the LH receptor-adenyl cyclase apparatus by a steroid response, it is advisable to use a more non-specific parameter of steroidogenic function than one specific component of secretion.

3. Hormones or drugs may exert an influence on the LH receptor population without modifying the maximum response of the Leydig cell to hCG/LH.

$27^{e}$ Congrès international des Sciences physiologiques, Symposium « Germ and somatic cell interaction 》 Paris, 21-23 juillet 1977. 
Acknowledgements. - Supported by grants from the World Health Organisation, the Norwegian Society for Fighting Cancer and the Norwegian Research Council for Science and the Humanities. We thank P. Torjesen and NIAMDD for the gifts of FSH and LH. We also thank Marian Purvis and Drude Andersen for skilled technical help, and Liv Lande Thon for typing the manuscript.

Résumé. Des cellules de Leydig de rats provenant de la même population testiculaire montrent des degrés différents dans la mise en évidence histochimique de la $3 \beta$-hydroxy stéroïde déhydrogénase et une fixation variable avec le $\mathrm{LH}$ quand on procède à un examen par immunofluorescence. Nous concluons que chaque cellule de Leydig de rat peut représenter une unité fonctionnelle dans une population cellulaire hétérogène, ayant des sensibilités individuelles envers $\mathrm{LH}$ et des capacités stéroïdogènes différentes.

La réponse in vitro des cellules de Leydig à une dose constante de HCG $(3 \mathrm{ng} / 2 \mathrm{ml})$ varie entre 30 et 80 jours d'âge. La valeur et le sens des changements dépendent du paramètre utilisé. Pour la sécrétion de testostérone, la capacité stéroïdogène et l'aptitude à répondre à HCG augmentent avec l'âge. Quand on prend comme critère la sécrétion des $17 \beta$-hydroxy androgènes (testostérone + métabolites $5 \alpha$ réduits) la tendance est inverse. Cette contradiction montre l'importance d'utiliser un paramètre correct pour évaluer les capacités stéroïdogènes et la réponse à $\mathrm{HCG} / \mathrm{LH}$ des cellules de Leydig du rat.

Une injection de HCG (75 $\mathrm{Ul})$ à un rat normal induit en 3 jours une réduction de 80 à 90 p. 100 des récepteurs membranaires à LH du testicule. Associée à cette diminution des récepteurs, on observait une réduction de la sensibilité de la réponse in vitro des cellules de Leydig à HCG. Cependant, la réponse maximale au niveau le plus élevé de HCG n'était pas affectée. La réduction du nombre de récepteurs $L H$ doit être supérieure à 30 p. 100 pour qu'un effet convaincant sur la réponse stéroïdogène des cellules de Leydig puisse être détecté. Les effets de la $L H$ envers les récepteurs à $L H$ et la réponse des cellules de Leydig peuvent expliquer la réduction observée dans la fixation de $\mathrm{LH}$ et dans ladim inution de la sensibilité des cellules de Leydig envers HCG, dans le syndrome de féminisation testiculaire, syndrome associé à un niveau très élevé de LH endogène.

Le traitement par le clomiphène de rats mâles normaux induit une augmentation de 2 à 3 fois du niveau de LH endogène et en même temps une réduction de 40 p. $100 \mathrm{du}$ nombre de récepteurs membranaires de LH des cellules de Leydig. Nous pensons que normalement le niveau de LH endogène peut être stimulé jusqu'au point où il influence le niveau de ses propres récepteurs.

Le traitement par la prolactine de rats hypophysectomisés provoque une stimulation du nombre des récepteurs à LH. La cyprotérone et le propionate de dihydrotestostérone (DHTP) sont sans effet sur les récepteurs à $\mathrm{LH}$, mais diminuent l'activité des cellules de Leydig par un effet sur les enzymes stéroïdogènes.

\section{References}

CATT K. J., TSURUHARA T., MENDELSON C., KETELSLEGERS J.-M., DUFAU M. L., 1974. Gona* dotropin binding and activation of the interstitial cells of the testis, 1-30. In DUFAU M. L., MEANS A. R., Hormone binding ond targef cell activation in the testis, Plenum Press, New York.

CHARREAU E. H., ATTRAMADAL A., TORJESEN P. A., PURVIS K., CALANDRA R., HANSSON V., 1977. Prolactin binding in rat testis : specific receptors in interstitial cells. Molec. cell. Endocr., 6, 303-307.

CLEGG E. J., 1966. Pubertal growth in the Leydig cells and accessory reproductive organs of the rat. J. Anat., 100, 369-379.

COFFEY J. C., FRENCH F. S., NAYFEH S. H., 1971. Metabolism of progesterone by rat testicular homogenates. IV., Further studies of testosterone formation of immature testis in vitro. Endocrinology, 89, 865-872. 
EVAIN D., MORERA A. M., SAEZ J. M., 1976. Glucocorticoid receptors in rat testis ; their role in the steroidogenesis and DNA synthesis of Leydig cells. Vth. int. Congr. Endocr., Hamburg, abstr. 524.

HSUEH A. J. W., DUFAU M. L., CATT K. J., 1976. Regulation of luteinizing hormone receptors in testicular interstitial cells by gonadotropin. Biochim. biophys. Res. Commun., 72, 1145-1152.

KNORR D. W., VANHA-PERTTULA T., LIPSETT, M. B., 1970. Structure and function of rat testis through pubescense. Endocrinology, 86, 1298-1304.

MATSUMOTO K., YAMADA M., 1973. $5 \alpha$ reduction of testosterone in vitro by rat seminiferous tubules and whole testes at different stages of development. Endocrinology, 93, 253-255.

MULDER E., VAN BEURDEN-LAMERS W. M. O., DE BOER W., BRINKMANN A. O., VAN DER MOLEN H. J., 1974. Testicular estradiol receptors in the rat, 343-355. In DUFAU M. L., MEANS A. R., Hormone binding and farget cell activation in the testis, Plenum Press, New York.

NAYFEH S. N., BAREFOOT Jr. S. W., BAGGETT B., 1966. Metabolism of progesterone by rat testicular homogenates II. Changes with age. Endocrinology, 78, 1041-1048.

ODELL W. D., SWERDLOFF R. S., BAIN J., WOLLESEN F., GROVER P. K., 1974. The effect of sexual maturation on testicular response to LH stimulation of testosterone. Endocrinology, 95, 13801384.

PAHNKE V. G., LEIDENBERGER F. A., KUNZIG H. W., 1975. Correlation between hCG (LH)-binding capacity, Leydig cell number and secretory activity of rat testis throughout pubescence. Acta Endocrinol. (Kbh) 79, 610-618.

PAYNE A. H., KELCH R. P., MURONO E. P., KERLAN J. T., 1977. Hypothalamic, pituitary and testicular function during sexual maturation of the male rat. J. Endocr., 72, 17-26.

PURVIS K., CALANDRA R., ATTRAMADAL A., HAUG E., RITZEN E. M., HANSSON V., $1976 a$. Effects of anti-androgens on testicular and adrenal function in immature rats. Int. Symp. on Androgens and Antiandrogens, Milan, April, 1976.

PURVIS K., CALANDRA R., NAESS O., ATTRAMADAL A., TORJESEN P. A., HANSSON V., 1976b. Do androgens increase Leydig cell sensitivity to luteinising hormone? Nature Lond., 265, 169-170.

PURVIS K., CLAUSEN O. P. F., BRANDTZAEG P., HANSSON V., 1978a. LH receptors and Leydig cell responsiveness to hCG in vitro. Arch. Andrology (in press).

PURVIS K., CLAUSEN O. P. F., HANSSON V., 1978b. Age-related changes in Leydig cell responsiveness : a question of the right hormonal parameter. J. Reprod. Fert. (in press).

PURVIS K., CLAUSEN, O. P. F., HANSSON V., 1978c. Decreased Leydig cell responsiveness in the testicular feminized male rat. Endocrinology (in press).

PURVIS K., HAUG E., CLAUSEN O. P. F., NAESS O., HANSSON V., 1977a. Endocrine status of the testicular feminised male (ffm) rat. Molec. cell. Endocr, 8, 317-334.

PURVIS K., TORJESEN P. A., HAUG E., HANSSON V., 1977b. hCG suppression of LH receptors and Leydig cell responsiveness to hCG. Molec. cell. Endocr., 8, 73-80.

RAFF M., 1976. Self regulation of membrane receptors. Nature Lond., 259, 265-266.

RODBARD D., 1973. Theory of hormone-receptor interaction III. The endocrine target cell as a quantal response unit : a general control mechanism. Adv. exp. Med. Biol., 36, 342-364.

SAR M., STUMPF W. E., MCLEAN W. S., SMITH A. A., HANSSON V., NAYFEH, S. N., FRENCH, F. S., 1975. Localization of androgen target cells in the rat testis : autoradiographic studies, 311 319. In FRENCH F. S., HANSSON V., RITZEN E. M., NAYFEH S. N., Hormonal regulation of spermatogenesis, Plenum Press, New-York.

SHARPE R. M., 1976. hCG-induced decrease in availability of rat testis recepfors. Nature Lond., 264, 644-645.

STANLEY A. J., GUMBRECK L. G., ALLISON J. E., EASLEY R. B., 1973. Male pseudohermaphroditism in the laboratory Norway rat. Recent Prog. Horm. Res., 29, 43-64.

STEINBERGER E., FICHER M., 1968. Conversion of progesterone to testosterone by testicular ti ssue at different stages of maturation. Steroids, 11, 351-368.

STRICKLAND A. L., NAYFEH S. N., FRENCH F. S., 1970. Conversion of cholesterol to testosterone and androstanediol in testicular homogenates of immature and mature rats. Steroids, 15 , 373-387.

WILSON E. M., SMITH A. A., 1975. Localization of androgen receptors in rat testis : bioch emical studies, 281-286. In FRENCH F. S., HANSSON V., RITZÉN E. M., NAYFEH S. N., Hormonal regulation of spermatogenesis, Plenum Press, New York. 